\title{
PELVIC PAIN IN A YOUNG PATIENT: SCLEROSING STROMAL TUMOR
}

\author{
Huriye Ayse PARLAKGUMUS ${ }^{1}$, Filiz Aka BOLAT ${ }^{2}$, Pinar Caglar AYTAC ${ }^{1}$, Esra Bulgan KILICDAG ${ }^{1}$ \\ ${ }^{1}$ Department of Gynecology and Obstetric, Baskent University, Faculty of Medicine, Ankara, Turkey \\ ${ }^{2}$ Department of Pathology, Baskent University, Faculty of Medicine, Ankara, Turkey
}

\begin{abstract}
SUMMARY
Introduction: Sclerosing stromal tumors are rare, benign sex chord stromal tumors. They are usually unilateral and are seen in second or third decades. The complaint at admission may be menstrual irregularity, pelvic pain, palpable pelvic mass, precocious puberty and postmenopausal bleeding. Because the complaint at admission and radiological findings are not specific to SSTs preoperative diagnosis is challenging. Herein we present the sonographical, intraoperative and histopathological findings of a SST diagnosed during laparoscopy in a patient who admitted with chronic pelvic pain and received pelvic inflammatory disease and endometriosis treatment and differential diagnosis of SSTs with the other ovarian tumors.

Case report: 24 years old nulliparous patient first admitted to the gynecology department with the complaint of foul smelling vaginal discharge and pelvic pain. The diagnosis was pelvic inflammatory disease and the patient received antibiotics. After the treatment the patient no longer complained of vaginal discharge but pelvic pain still persisted. The pelvic examination was normal except the mass in the right ovary which had similar echogenity to the ovary. Because of the pelvic pain the mass was assumed to be an endometrioma and the patient was prescribed an oral contraceptive treatment for 3 months. Because of the persistent pelvic pain a diagnostic laparoscopy was performed which revealed a $2 \mathrm{~cm}$, pinkish-white, exophytic lesion originating from the right ovary. Pathological examination reported the mass to be a sclerosing stromal tumor. After the operation the patient no longer complained of pelvic pain.

Conclusion: Although SSTs are rare, they should be kept in mind when a young patient admits with menstrual irregularity, pelvic pain and hirsutism, particularly if the pain is refractory to treatment.
\end{abstract}

Key words: hirsutism, pelvic pain, sclerosing stromal tumors

Journal of Turkish Society of Obstetrics and Gynecology, (J Turk Soc Obstet Gynecol), 2013; Vol: 10, Issue: 1, Pages: 53- 7

\section{GENÇBİR HASTADA PELVIK AĞRI: SKLEROZAN STROMAL TÜMÖR}

\section{ÖZET}

Giriş: Sklerozan stromal tümörler (SST) nadir görülen, benign karakterde seks kord stromal tümörlerdir. Genellikle tek taraflıdırlar ve ikinci veya üçüncü dekadda görülürler. Başvuru şikâyeti adet düzensizlikleri, kasık ağrısı, palpe edilebilen pelvik kitle, prekoks puberte ve postmenopozal kanama olabilir. Başvuru şikâyetleri ve radyolojik bulgular SST'lere özgül olmadığı iç in ameliyat öncesi tanı koymak güç tür. Biz bu yazıda kliniğimize kronik pelvik ăgrı şikâyeti ile başvurmuş ve pelvik inflamatuar hastalık ve endometriosis tedavisi verilmiş, ancak laparoskopi sonrast SST tanısı almış bir olguya ait ultrasonografi, operasyon bulgularını, tumörün histopatolojik özelliklerini ve SST'lerin over

Address for Correspondence: Dr. Huriye Ayşe Parlakgümüş. Başkent Üniversitesi Seyhan Uygulama Hastanesi Cemal Paşa Mah. 01110 Adana Phone: + 90 (532) 6745405

e-mail: ayseparlakgumus@yahoo.de

Received: 21 January 2012, revised: 21 January 2012, accepted: 03 August 2012, online publication: 05 August 2012 
tümörleri ile ayırıcısı tanısını sunuyoruz.

Vaka takdimi: 24 yaşında nullipar hastanın jinekoloji kliniğine ilk başvuru şikâyeti kötü kokulu akıntı ve kasılk ă̆rısı idi. Hastada pelvik inflamatuar hastalık düşünülerek antibiyotik tedavisi verildi. Tedavi sonrası yapılan kontrolünde akıntı şikâyeti kalmamasına rağmen ă̆rısı devam etmekte idi. Ultrasonografide să̆ overde görülen over dokusuna benzer ekojenite gösteren 15 mm kitle dışında pelvik muayenesi normaldi. Ağrı şikayeti olmasından dolayı kitlenin endometrioma olabileceği düşünülerek oral kontraseptif verildi. Pelvik ağrı şikayetinin devam etmesi üzerine yapılan tanısal laparoskopide sağ over üzerinde egzofitik gelişmiş pembe-beyaz renkli yaklaşık $2 \mathrm{~cm}$ büyüklüğünde bir lezyon mevcuttu. Kitlenin patolojik incelemesi sonucu sklerozan stromal tümör olarak rapor edildi. Postoperatif hastanın ă̆rı şikâyeti kalmadı.

Sonuç: SST'ler nadir görülmelerine rağmen pelvik ağrl, adet düzensizliği, hirsutizm gibi sebeplerle başvuran genç hastalarda, özellikle de tedaviye dirençli ağrl şikâyeti olanlarda, düşünülmesi gereken tümörlerdir.

Anahtar kelimeler: hirsutizm, pelvik ağrl, sklerozan stromal tümör,

Türk Jinekoloji ve Obstetrik Dernĕgi Dergisi, (J Turk Soc Obstet Gynecol), 2013; Cilt: 10, Sayl: 1, Sayfa: 53-7

\section{INTRODUCTION}

Sclerosing stromal tumors (SST) are rare, benign sex chord stromal tumors frequently encountered during the second or the third decade ${ }^{(1)}$. They are usually unilateral. Patients may present with menstrual irregularities, pelvic pain, palpable pelvic mass, menorrhagia, precox puberty, and post menopausal bleeding(2-4).

Hirsutism or virilization may be present if the tumor is hormonally active ${ }^{(3)}$. Preoperative diagnosis of SST is challenging because the complaints at admission and radiologic imaging are non- specific. The definitive diagnosis is only possible by histopathologic examination.

In this case report we present the sonographic, operative and histopathologic findings of a patient who admitted our clinic with the complaint of pelvic pain, received treatment for pelvic inflammatory disease and endometriosis and finally diagnosed as SST after laparoscopy. We also discuss the differential diagnosis of SST.

\section{Case report}

A 24 years old, nulliparous patient admitted the gynecology clinic with foul smelling discharge and pelvic pain. The patient reported that the pelvic pain was felt in the right inguinal area had started few months ago, but worsened in the last month. Pelvic examination revealed mixed vaginitis, cervix was normal, cervical motion, and palpation of the uterus and adnexa was tender. Ultrasound revealed normal uterus and adnexa. No blood tests were ordered at the first admission. The patient was prescribed levofloxacin $400 \mathrm{mg}$ po once a day and metronidazole $500 \mathrm{mg}$ po twice a day for 14 days for pelvic inflammatory disease (PID). After the treatment the patient reported that she no longer had vaginal discharge but the pain had not improved. Pelvic examination was normal except the tenderness in the uterus and adnexa. WBC were 5900, and CRP $<3$. Although the laboratory results were not concordant with the diagnosis of PID, the patient was hospitalized because to give iv antibiotics. The patient received gentamycin $80 \mathrm{mg}$ iv and cleosin $900 \mathrm{mg}$ iv three times a day. After the 5th day of the iv antibiotics the patient had another examination because she reported no improvement in pain. This examination revealed $15 \mathrm{~mm}$ exophytic lesion of the right ovary. The echogenity was similar to the ovary (Figure 1). CA 125 levels were normal. Because of the accompanying pelvic pain the lesion was considered to be an endometrioma. The patient was prescribed an oral contraceptive (OC) treatment for 3 months After 3 months the patient reported no change in the intensity of pelvic pain. Pelvic examination was normal except the $15 \mathrm{~mm}$ mass diagnosed before. The patient was offered a diagnostic laparoscopy, but she did not accept. Therefore she was prescribed OC treatment for another three months and fluoxetine to relieve the anxiety. The patient reported increased pelvic pain in the control and she accepted the operation. This time the pelvic mass was recorded to be $20 \mathrm{~mm}$. During the laparoscopy a $2 \mathrm{~cm}$, whitish pink exophytic lesion was present on the right ovary (Figure 2). The lesion was removed by bipolar electrocautery. No complication occurred during or after the operation and the patient was discharged successfully. 


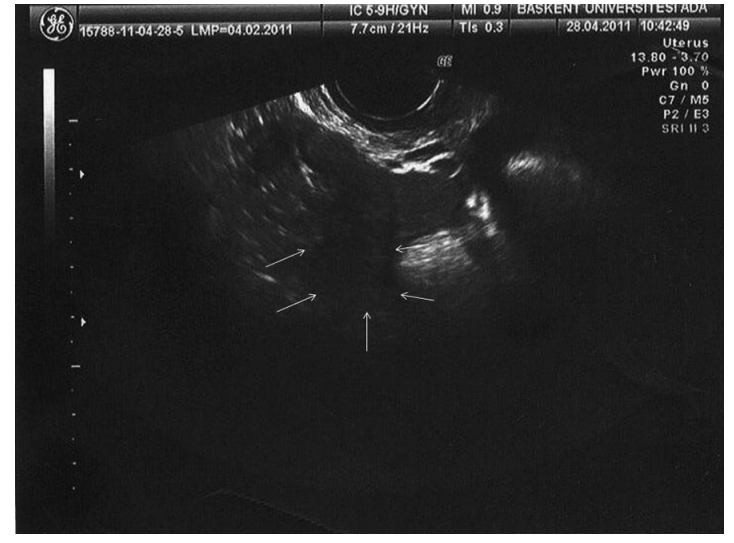

Figure 1: Sclerosing stromal tumor located on right ovary exophytically, sonophraphy.

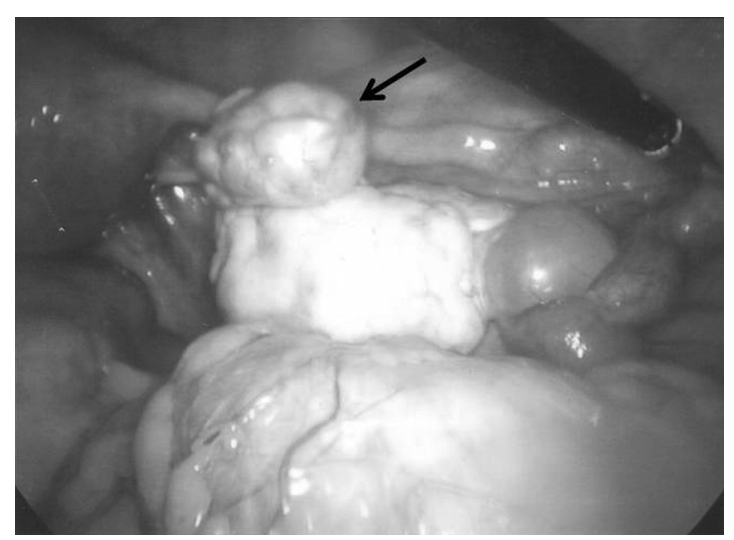

Figure 2: Sclerosing stromal tumor, exophytically located on right ovary, laparoscopic findings.

The mass was macroscopically $1.6 \times 1.5 \times 0.8 \mathrm{~cm}$ big, whitish-grey solid. The section revealed yellowish white, cystic myxoid areas. The microscopic examination revealed typical pseudolobular pattern: compact cellular areas surrounded by hypocellular areas (Figure 3a). The hypocellular areas were composed of edematous and collagenous stroma and had two types of cells: fibroblast like fusiform cells and polygonal cells with dark, big nucleus and eosinophilic cytoplasm with clear vacuoles. The vessels were thin, ectatic and hemangioperistioma like (Figure $3 b)$. The nucleus was eccentrically located in some of the polygonal cells and resembled signet ring cells. Nuclear atypia and/or mitosis were not present. Immunohistochemical examination revealed strong positive staining for inhibin, calretinin and vimentin (Figure 3c). Smooth muscle actin was focally positive. Desmin was negative. Progesteron receptor antibody (PR) and estrogen receptor antibody (ER) were positive. Keratin and epithelial membrane-antigen (EMA) were negative. Hemangiperisitoma like ectatic vessels were positively stained for CD 34. The morphological and immunohistochemical findings supported sclerosing stromal tumor of the ovary.

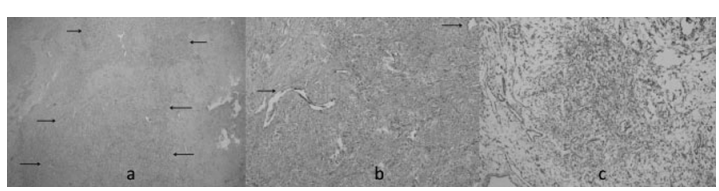

Figure 3a: The psudolobular pattern cells composed of areas poor in cells and cellular areas $x$ 40). b: Polygonal cells with cytoplasmic vacuoles between ectatic vessels (arrows) (Hematoxilen-eosin $x$ 100). : Strong positive staining with calretinin in polygonal cells (calretinin $x$ 100).

When the patient was seen 15 days after the operation in the clinic she reported that the pain relieved and she felt very well. The patient still comes to visits every 3 months and she still does not have pain. Written informed consent was obtained from the patient before preparation of this report.

\section{DISCUSSION}

Sclerosing stromal tumors are rare sex chord stromal tumors. They constitute less than 5 percent of sex chord stromal tumors $^{(2)}$. It was first reported in 1973 by Chalvardjian and Scully ${ }^{(5)}$. Later Peng et al. reported 114 cases until 2003 (6). SSTs usually present in the second and third decade in contrast to other stromal tumors which are most common in the fifth and sixth decade $(7,8)$. The mean age of SSTs at diagnosis is 28 (2).

The complaints at admission are non-specific in most of the patients such as menstrual irregularities, pelvic pain, palpable pelvic mass and menorrhagia. The tumors may present with postmenopausal bleeding in older patients, and puberte precox in children ${ }^{(2-4)}$.

Although most of the SSTs are non-functional, SSTs can cause anovulation and infertility. Gee and Russell reported that in 2 of the 5 patients the tumor had estrogenic activity ${ }^{(10)}$. Damjanov et al. reported a case in whom urinary secretion of estrogens and androgens reduced after the tumor excision ${ }^{(11)}$. In the postoperative period ovulation resumed and menstruation became regular. If the tumor is hormonally active it usually shows androgenic activity. Virilization is reported in one premenarche girl and in three pregnant patients ${ }^{(3,11,12)}$. Cashell et al. reported hirsutism in a 
pregnant women with SST. The hormonal levels returned to normal after tumor excision and the patient delivered a female baby without the signs of virilization. (11). İsmail and Walker reported bilateral SST and hirsutism in a pregnant women with Gorlin syndrome (12). Gürbüz et al. performed laparatomy in a 14 weeks old pregnant woman for rapidly enlarging pelvic mass and pathology was reported as $\operatorname{SST}^{(13)}$. Gulati et al reported the presence of endometriotic implants(14) and Akbulut et al. torsion(15) with SSTs. Although some reports reported high CA 125 levels in SSTs none of the tumor markers are specific for $\operatorname{SSTs}^{(16,}$ 17).

Preoperative radiologic diagnosis is challenging. Sonographically SSTs are cystic or solid masses with centrally located multiple small cysts or clefts. Color Doppler imaging shows increased vascularity between the periphery of the cyst and centrally located cysts. MRI shows a low density nodules located inside the high density stroma, strong enhancement with gadolinium and low intensity in the periphery of the cyst(18).

Although MRI findings are useful for differential diagnosis the definitive diagnosis is by histopathological examination. Histopathologically ovarian SSTs show pseudolobular pattern with focal areas of sclerosis, fibroblasts and fibroblast like fusiform cells, polygonal cells containing lipid globules which resemble theca cells, edematous stroma and hemangioperiostoma like vessels.

The differential diagnosis of SST includes fibroma, thecoma, massive ovarian edema, juvenile granulosa cell tumors, and Krukenberg tumors. When the SSTs are big, solid and in older patients they can be misdiagnosed as malignant ovarian tumors.

In the differential diagnosis with thecofibroma histopathologically pleomorphic cell rich cellular zona and rich vascularity and the patients age may be useful. The preservation of the stromal ovarian features and heterogeneity may help in the diagnosis with massive ovarian edema(19).

When the juvenile granulosa cell tumor has prominent sclerosis it can be misdiagnosed as SST. Follicular development, high mitotic activity and characteristic granulosa cell morphology may be used in differential diagnosis.

Although polygonal theca cells with vacuoles may resemble malignant tumors like Krukenberg tumors, other morphological findings, mucin in signet ring cells in Krukenberg tumors and positive staining for keratin and EMA are important in the differential diagnosis.

The etiology of SST is not definitely known. An ultra structural study reported that SSTs may originate from pluripotent immature stromal cells in the ovarian cortex (12). SSTs are also reported to originate from actin positive cells of theca externa which are named as myxoid stromal cells. In our case focal actin positivity was present in the polygonal and fusiform cells ${ }^{(20)}$.

Surgical excision of the tumor is adequate for SSTs. Local or distant metastasis is not reported.

The patient we reported was 24 years old and her complaint was pelvic pain. Although the age and complaint of the patient was suggestive of SST, because of the rareness of SSTs and accompanying infection the initial diagnosis was PID. The pain did not resolve upon recovery of the infection, the mass seen at the sonography was considered to be an endometrioma and the patient received treatment for endometriosis. The mass was $2 \mathrm{~cm}$ big, and its echogenity was similar to the ovarian cortex. It was solid and CA 125 level was normal. Because of the aforementioned reasons, preoperative diagnosis was not possible. Although the tumor was small the patient reported significant pain which affected routine of the day. The pain resolved upon excision of the tumor.

Conclusion: Although SSTs are rare they should be remembered in the differential diagnosis in young patients who admit clinics with pelvic pain, menstrual irregularity and especially in those with pain resistant to treatment.

\section{REFERENCES}

1. Kuscu E, Oktem M, Karahan H, Bilezikci B, Demirhan B. Sclerosing stromal tumor of the ovary. Eur J Gynaecol Oncol. 2003; $24: 442-4$.

2. Youm HS, Cha DS, Han KH, Park EY, Hyon NN, Chong Y. A case of huge sclerosing stromal tumor of the ovary weighing $10 \mathrm{~kg}$ in a 71-year-old postmenopausal woman. J Gynecol Oncol. 2008;19(4): 270- 4. Epub 2008 Dec 29.

3. Park SM, Kim YN, Woo YJ, Choi HS, Lee JS, Heo SH, Kim CJ. A sclerosing stromal tumor of the ovary with masculinization in a premenarchal girl. Korean J Pediatr. 2011;54(5): 224- 7. Epub 2011 May 31.

4. Murthy DP, SenGupta SK, Mola G, Rageau O, Mathias A. 
Sclerosing stromal tumour of the ovary. P N G Med J 1996; 39: $48-55$

5. Russell P, Farnsworth A. Surgical Pathology of the Ovaries. 2nd ed. New York: Churchill Livingstone; 1997: 422

6. Peng H, Chang T, Hsueh S. Sclerosing stromal tumor of the ovary. Chang Gung Med J. 2003; 26: 444 - 7.

7. Irving JA, Young RH. Microcystic stromal tumor of the ovary: Report of 16 cases of a hitherto uncharacterized distinctive ovarian neoplasm. Am J Surg Pathol 2009; 33: 367- 75.

8. Charfi Darghouth L, Goutallier Ben Fadhel C, Lahmar A, Mestiri H, Khalfallah MT, M'Zabi Regaya S. Sclerosing stromal tumor of the ovary: A case report and literature review] Tunis Med 2007; 5: 430- 2.

9. Fox H, Wells M. Haines and Taylor Obstetrical and Gynecological Pathology. 5th ed. New York: Cherchill Livingstone; 2003: 842 - 3 .

10. Gee DC, Russell P. Sclerosing stromal tumours of the ovary. Histopathology 1979; 3: 367- 76.

11. Damajanov I, Drobnjak P, Grizelj V, Longhino N. Sclerosing stromal tumor of the ovary: A hormonal and ultrastructural analysis. Obstet Gynecol 1975; 45: 675- 9.

12. Cashell AW, Cohen ML. Masculinizing sclerosing stromal tumor of the ovary during pregnancy. Gynecol Oncol. 1991; 43(3): 281- 5 .

13. Ismail SM, Walker SM. Bilateral virilizing sclerosing stromal tumours of the ovary in a pregnant woman with Gorlin's syndrome: implications for pathogenesis of ovarian stromal neoplasms. Histopathology 1990; 17: 159- 63.
14. Gurbuz A, Karateke A, Kabaca C, Gaziyiz GO, Kir G Sclerosing stromal cell tumor of the ovary in pregnancy: a case report. Eur J Gynaecol Oncol. 2004; 25(4): 534- 5.

15. Gulati A, Kaushik R, Sharma J. Sclerosing stromal tumor of the ovary associated with benign endometrioid peritoneal implants. Indian J Pathol Microbiol 2009; 52: 594- 5.

16. Akbulut M, Türk NS, Altınboga AA, Soysal ME. Sclerosing stromal tumor in a postmenopausal woman with an ovarian Torsion. Pam Med J 2011; 4(1): 39- 42.

17. Amorim-Costa C, Costa A, Baptista P, Paiva V. Sclerosing stromal tumour of the ovary associated with Meigs' syndrome and elevated CA125. J Obstet Gynaecol. 2010; 30(7): 7478.

18. Terauchi F, Onodera T, Nagashima T, Kobayashi Y, Moritake T, Oharaseki T, Ogura H. Sclerosing stromal tumor of the ovary with elevated CA125. J Obstet Gynaecol Res. 2005; 31(5): 432- 5.

19. Calabrese M, Zandrino F, Giasotto V, Rissone R, Fulcheri E. Sclerosing stromal tumor of the ovary in pregnancy: clinical, ultrasonography, and magnetic resonance imaging findings. Acta Radiol 2004; 45: 189- 92.

20. Swan JA. Shaw JA, Dabbs DJ, Geisinger KR. Sclerosing stromal tumor of the ovary: an ultrastructural and immunohistochemical analysis with histogenetic considerations. Ultrastruct Pathol. 1992; 16(3): 363- 77.

21. Dilbaz B, Taşcı Y, Ulular N, Demir OF, Goktolga U. Overin Sklerozan Stromal Tümörü. J Tturk Soc Obstet Gynecol, 2011; 8(4): 286- 8 